\title{
Epibiotic sponges on the hairy triton Fusitriton magellanicus in the SW Atlantic Ocean, with the description of Myxilla (Styloptilon) canepai sp. nov.
}

\author{
Laura Schejter ${ }^{1, *}$, Marco Bertolino $^{2}$, Barbara Calcinai $^{2}$, Carlo Cerrano ${ }^{3}$, \\ Claudia Bremec ${ }^{1}$
}

\author{
${ }^{1}$ Consejo Nacional de Investigaciones Científicas y Técnicas (CONICET), \\ Instituto Nacional de Investigación y Desarrollo Pesquero (INIDEP), Paseo Victoria Ocampo 1, 7600 Mar del Plata, Argentina \\ ${ }^{2}$ Università Politecnica delle Marche, 60131 Ancona, Italy \\ ${ }^{3}$ Dipartimento per lo Studio del Territorio e delle sue Risorce, 16132 Genova, Italy
}

\begin{abstract}
In the present study we identified a total of 26 sponge taxa, to be added to the 4 sponge species previously registered, living epizoically on Fusitriton magellanicus shells, an abundant and frequent gastropod in the shelf-break frontal area of the Argentine Sea, SW Atlantic Ocean. The majority of the recorded sponges were encrusting living specimens of this gastropod, the most frequent ones being Hymedesmia (Stylopus) antarctica (20\%), Clathria spp. (18\%), Dictyonella spp. (13\%) and Tedania spp. (9\%) We described one species, Myxilla (Styloptilon) canepai sp. nov., and extended the distribution of Clathria (Microciona) antarctica and Stelodoryx cribrigera northwards. We also registered, for the second time after its description, the species Stelodoryx argentinae. Considering that the study area is a soft bottom and the only available substrates for settlement of sessile species are either external mineralized skeletons of living organisms, empty shells or crustacean carapaces, we conclude that shells of the gastropod F. magellanicus play a very important role for settlement of sponge species in the area. Moreover, possibly only living F. magellanicus (not the empty or pagurized shells) are important as a settlement substrate because the few specimens found in empty shells could be considered as rare occurrences.
\end{abstract}

KEY WORDS: Porifera $\cdot$ Fusitriton magellanicus $\cdot$ Myxilla $\cdot$ New species $\cdot$ Epibiosis $\cdot$ Argentine Sea -SW Atlantic Ocean · Settlement substrate

Resale or republication not permitted without written consent of the publisher

\section{INTRODUCTION}

The shelf-break frontal area in the Argentine Sea is one of the most productive ecosystems in the SW Atlantic Ocean (Acha et al. 2004, Bogazzi et al. 2005); this region supports a high biological production as a consequence of high levels of nutrients and chlorophyll (Carreto et al. 1986, Rivas 2006, Romero et al. 2006). In general, shelf-break frontal areas accumulate floating material and invertebrate larvae (Largier 1993, Mann \& Lazier 1996), however the shelf-break frontal area of the Argentine Sea is also character- ized by the presence of extensive beds of Patagonian scallop Zygochlamys patagonica (King, 1832), a pectinid species exploited since 1996 (Lasta \& Bremec 1998). This benthic habitat is dominated by soft bottoms (sand and mud). Approx. $70 \%$ of the Argentinean continental shelf (including shelf-break frontal areas) is soft bottom habitat (Parker et al. 1997).

Given the lack of rocks or hard bottoms in this region, sessile species mostly depend on epibiotic relationships to survive (Schejter \& Bremec 2007, 2008, Schejter et al. 2008). All solid living and non- 
living surfaces represent possible settlement sites for sessile species, playing a very important role by functioning as stepping-stones for their dispersal (Kimura $\&$ Weiss 1964). The availability of a suitable substrate is a critical factor not only in the colonization of sessile species (Wahl 1989), but also in the primary settlement of many other non-sessile species, such as the Patagonian scallop (Bremec et al. 2008).

The benthic species richness of the shelf-break frontal area of the Argentine Sea is increased by epibiotic relationships, as demonstrated by Schejter \& Bremec (2007, 2008, 2009), Schejter et al. (2008) and Escolar et al. (2008). At least 41 taxa have been found attached or encrusting shells (living organisms and empty shells) of the Patagonian scallop (Schejter \& Bremec 2007), although this number has been recently increased after the specific identification of bryozoans (López Gappa \& Landoni 2009) and sponges (Schejter et al. 2010). However, other species in the benthic community of the shelf-break frontal area of the Argentine Sea have also been found to host epibiotic organisms, such as spider crabs, brachiopods, volutids and also the hairy triton Fusitriton magellanicus (Röding, 1798), all conspicuous members of the benthic assemblage (Bremec \& Lasta 2002, Bremec et al. 2003, Schejter \& Spivak 2005, Escolar et al. 2008, Schejter et al. 2010). More than $70 \%$ of living F. magellanicus in the Patagonian scallop-fishing grounds host encrusting organisms and empty and pagurized shells are also used as settlement substrates by a variety of sessile taxa (Schejter et al. 2011). Considering these facts, F. magellanicus is probably the second most important living substrate colonized by encrusting organisms in this community, hosting at least 30 epibiotic taxa. However, sponges were grouped by Schejter et al. (2011) into a single major taxon, with the only exceptions being one conspicuous known species and 2 other species identified to the genus level. Therefore, the objectives of this study were to: (1) identify the sponge species living epizoically on $F$. magellanicus shells, (2) determine whether the sponges prefer empty shells or living gastropods to settle and grow and (3) establish whether this gastropod plays an important role as a settlement substrate for sponges in the study area.

\section{MATERIALS AND METHODS}

We studied living, empty and pagurized shells of Fusitriton magellanicus that were collected between $37^{\circ} 00.27^{\prime}$ and $45^{\circ} 01.70^{\prime} \mathrm{S}$ and $54^{\circ} 40.46^{\prime}$ and $60^{\circ} 25.62 \mathrm{~W}$, along the $100 \mathrm{~m}$ isobath and between 81 and $150 \mathrm{~m}$, during 3 research cruises in 2007 and 2008 (Fig. 1). The study material was collected as part of the epibenthic assemblage of Zygochlamys patagonica fishing grounds located in the shelfbreak frontal area of the Argentine Sea. Benthic samples were frozen on board and analyzed in the laboratory at the Instituto Nacional de Investigación y Desarrollo Pesquero (INIDEP - Argentina). In total, 194 sites were sampled using bottom otter trawls and dredges during monitoring cruises onboard the RV 'Capitán Cánepa' (October 2007, Northern Management Unit) and the FVs 'Miss Tide' (July 2008) and 'Atlantic Surf III' (November 2008) (Southern Management Unit, both cruises) (Fig. 1). Only 123 sites were positive for the presence of $F$. magellanicus. A total of 443 living F. magellanicus specimens, 86 empty shells and 27 pagurized shells were separated from total benthic samples and carefully studied for the detection of sponges. Shells hosting sponges were carefully labeled and dried.

For sponge species identification, we used the classic methodology based on identification and quantification of spicules, and the observation of spicule arrangement in the skeleton. This methodology was described by Rützler (1978) and is used worldwide. Spicules were cleaned by means of nitric acid and heat, and then dehydrated by ethylic alcohol and prepared for microscopical observation. Spicule dimensions (length and width) were obtained measuring 40 spicules per slide. The SEM studies were carried out using a Philips XL 20 scanning electron microscope. For SEM analyses, dissociated spicules were transferred onto stubs and sputtered with gold.

Valid species names, global distribution and other relevant information were checked in Van Soest et al. (2011) and López Gappa \& Landoni (2005).

\section{RESULTS}

\section{Epibiotic sponges registered on the hairy triton}

From the 123 sampled sites positive for the presence of Fusitriton magellanicus ( $\mathrm{N}=556$ shells), only 56 were positive for the presence of epibiotic sponges on the shells ( $\mathrm{N}=117$ shells) (Fig. 1). Overall, 21 percent of the sampled shells (living organisms, empty shells and pagurized shells) were encrusted by sponges. In total, 26 sponge taxa attached to F. magellanicus shells were identified during this study (Table 1). However, because of scarce cover or bad preservation of the samples, approximately $20 \%$ of 


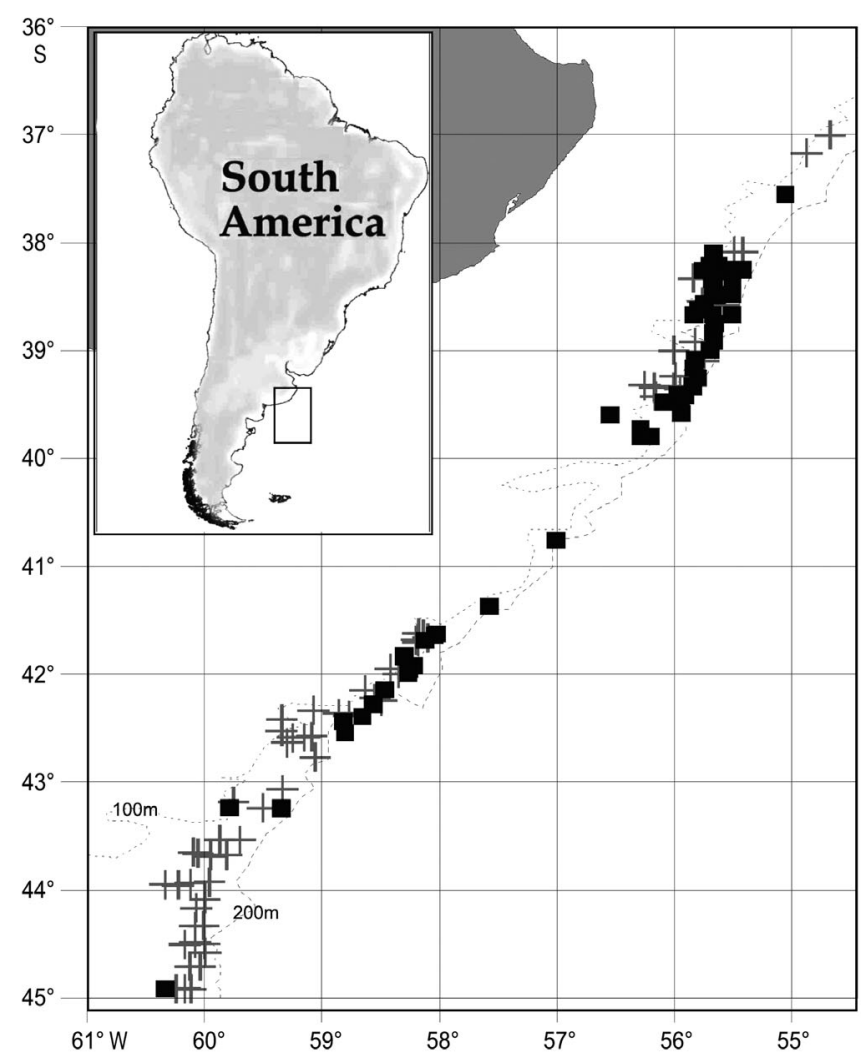

Fig. 1. Sites sampled for Fusitriton magellanicus in the shelfbreak frontal area of the Argentine Sea. Black squares: positive sites for the presence of epibiotic sponges on F. magellanicus; crosses: positive sites for the presence of F. magellanicus, but those sampled organisms (or shells) did not present epibiotic sponges

the sponges encrusting the gastropod remained unidentified.

The most frequent sponge species encrusting living individuals of Fusitriton magellanicus were Hymedesmia (Stylopus) antarctica Hentschel, 1914 (on $20 \%$ of sampled specimens), Clathria spp. (on $18 \%$ of sampled specimens), Tedania spp. (on $9 \%$ of sampled specimens) and Dictyonella spp. (on $7 \%$ of sampled specimens) (Fig. 2).

The majority of Fusitriton magellanicus hosted only one sponge species, however, $6 \%$ of the living gastropods were conspicuously and simultaneously encrusted by 2 sponge species (e.g. Fig. 2j). In this sample, a large Tedania (Trachytedania) mucosa Thiele, 1905 encrusted the majority of the shell, but a small portion was also encrusted by Stelodoryx argentinae Bertolino, Schejter, Calcinai, Cerrano \& Bremec, 2007. This sample was preserved and deposited as reference material for $S$. argentinae at the Museo Argentino de Ciencias Naturales 'Bernardino Rivadavia' MACN-IN 39417. T. mucosa was assigned the reference number MACN-IN 39416. Reference material for Hymedesmia (Stylopus) antarctica (F45N) MACN-IN 39418 was also deposited at the museum (see Table 1 for locations).

Six sponge species (considering the 2 additional records from other studies) were found encrusting empty or pagurized shells (Table 1) of which 4 were only found encrusting non-living shells. One sponge species, Hymedesmia (Stylopus) antarctica, was either found encrusting living, empty or pagurized shells, while Tedania (Trachytedania) mucosa was found encrusting either living or empty shells.

In the majority of gastropod species, only a small portion of the shell surface, detectable to naked eye, was covered by the epizoic sponges. In these cases the sponge external morphology and skeleton were almost impossible or very difficult to elucidate. In contrast, other sponge species (Suberites sp., Tedania [Trachytedania] mucosa, Clathria spp., Hymedesmia [Stylopus] antarctica) heavily fouled some other gastropod shells (Fig. 2).

\section{Description of Myxilla (Styloptilon) canepai sp. nov.}

Order Poecilosclerida Topsent, 1928

Suborder Myxillina Hajdu, Van Soest \& Hooper, 1994

Family Myxillidae Dendy, 1922

Genus Myxilla Schmidt, 1862

Subgenus Myxilla (Styloptilon) Cabioch, 1968

Myxilla (Styloptilon) canepai sp. nov.

\section{Type material}

Holotype. Dried sample epibiotic on Fusitriton magellanicus. Additionally, we provided tissue sections and spicule preparations on slides taken from this sponge and shown in Fig. 3. The material was deposited in the collection of Museo Argentino de Ciencias Naturales 'Bernardino Rivadavia', Buenos Aires Argentina, numbered as MACN-IN 38292.

Type locality. Argentine Sea, $38^{\circ} 40.17^{\prime} \mathrm{S}$ and $55^{\circ} 50.06^{\prime} \mathrm{W}_{i} 87 \mathrm{~m}$ depth (Zygochlamys patagonica fishing grounds). Collected by Laura Schejter.

Etymology. Named after the RV 'Capitán Cánepa' (Instituto Nacional de Investigación y Desarrollo Pesquero, Argentina), the ship used during the evaluation and monitoring cruises of the Zygochlamys patagonica fishing grounds performed in the last decade.

Description. Thinly encrusting sponge, approximately $2 \mathrm{~mm}$ in thickness. The fresh sponge was beige, but became beige-grey after dried. The 
Table 1. Sponge species registered encrusting living, empty or pagurized shells of Fusitriton magellanicus. Latitude, longitude, depth of the collection site and code assigned to the specimen are given for every record. s/n: an identified sponge species not preserved in the collection; \#: a record of a specimen mentioned in Schejter et al. (2008), but not recorded during the present sampling

\begin{tabular}{|c|c|c|c|c|}
\hline \multirow{2}{*}{ Porifera taxa } & \multicolumn{3}{|c|}{ Fusitriton magellanicus } & \multirow{2}{*}{ Latitude, longitude, depth (sample code) } \\
\hline & Living & $\begin{array}{l}\text { Empty } \\
\text { shell }\end{array}$ & $\begin{array}{l}\text { Pagurized } \\
\text { shell }\end{array}$ & \\
\hline $\begin{array}{l}\text { Amphilectus fucorum } \\
\text { (Esper, 1794) }\end{array}$ & $\mathrm{x}$ & & & $38^{\circ} 40.17^{\prime} \mathrm{S} 55^{\circ} 50.06^{\prime} \mathrm{W} 87 \mathrm{~m}(\mathrm{~F} 27 \mathrm{~N})$ \\
\hline $\begin{array}{l}\text { Callyspongia (Callyspongia) } \\
\text { ramosa (Gray, } 1843)\end{array}$ & & $\mathrm{x}$ & & $39^{\circ} 19.84^{\prime} \mathrm{S} 55^{\circ} 50.33^{\prime} \mathrm{W} 121 \mathrm{~m}(\mathrm{~F} 10 \mathrm{~N})$ \\
\hline $\begin{array}{l}\text { Calyx kerguelensis } \\
\text { (Hentschel, 1914) }\end{array}$ & & $\mathrm{x}$ & & $39^{\circ} 59^{\prime} \mathrm{S} 56^{\circ} 40^{\prime} \mathrm{W} 93 \mathrm{~m}(\#)$ \\
\hline Calyx sp. & & $\mathrm{x}$ & & $39^{\circ} 34.95^{\prime} \mathrm{S} 55^{\circ} 56.36^{\prime} \mathrm{W} 130 \mathrm{~m}(\mathrm{~F} 23 \mathrm{~S})$ \\
\hline Chalinula sp. & $\mathrm{x}$ & & & $39^{\circ} 24.53^{\prime} \mathrm{S} 55^{\circ} 56.20^{\prime} \mathrm{W} 107 \mathrm{~m}(\mathrm{~F} 31 \mathrm{AN})$ \\
\hline $\begin{array}{l}\text { Clathria (Clathria) microxa } \\
\text { Desqueyroux, } 1972\end{array}$ & & $\mathrm{x}$ & & $41^{\circ} 41^{\prime} \mathrm{S} 58^{\circ} 09^{\prime} \mathrm{W} 92 \mathrm{~m}(\#)$ \\
\hline $\begin{array}{l}\text { Clathria (Microciona) } \\
\text { antarctica (Topsent, 1917) }\end{array}$ & $\mathrm{x}$ & & & $38^{\circ} 20.02^{\prime} \mathrm{S} 55^{\circ} 30.22^{\prime} \mathrm{W} 106 \mathrm{~m}(\mathrm{~F} 32 \mathrm{BN})$ \\
\hline $\begin{array}{l}\text { Clathria (Microciona) spp. } \\
\text { (at least } 2 \text { species) }\end{array}$ & $\mathrm{x}$ & & & 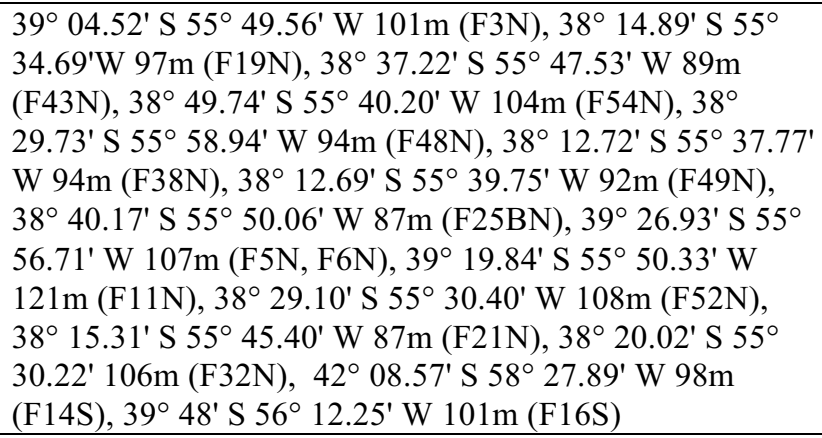 \\
\hline $\begin{array}{l}\text { Dasychalina validissima } \\
\text { (Thiele, 1905) }\end{array}$ & $\mathrm{x}$ & & & $41^{\circ} 40^{\prime} \mathrm{S} 58^{\circ} 02^{\prime} \mathrm{W} 96 \mathrm{~m}(\#)$ \\
\hline $\begin{array}{l}\text { Dictyonella hirta (Topsent) } \\
\text { sensu Burton, } 1940\end{array}$ & $\mathrm{x}$ & & & $\begin{array}{l}38^{\circ} 20.02^{\prime} \mathrm{S} 55^{\circ} 30.22^{\prime} \mathrm{W} 106 \mathrm{~m}(\mathrm{~F} 32 \mathrm{AN}), 41^{\circ} 38.58^{\prime} \mathrm{S} 58^{\circ} \\
20.36^{\prime} \mathrm{W} 96 \mathrm{~m}(\mathrm{~F} 2 \mathrm{~S}), 42^{\circ} 16.73^{\prime} \mathrm{S} 58^{\circ} 34.08^{\prime} \mathrm{W} 119 \mathrm{~m} \\
(\mathrm{~s} / \mathrm{n}), 40^{\circ} 45^{\prime} \mathrm{S} 57^{\circ} 00^{\prime} \mathrm{W} 105 \mathrm{~m}(\#)\end{array}$ \\
\hline Dictyonella $\mathrm{sp}$. & $\mathrm{x}$ & & & $\begin{array}{l}38^{\circ} 40.11^{\prime} \mathrm{S} 55^{\circ} 30.75^{\prime} \mathrm{W} 120 \mathrm{~m}(\mathrm{~F} 24 \mathrm{~N}), 38^{\circ} 29.73^{\prime} \mathrm{S} 55^{\circ} \\
38.94^{\prime} \mathrm{W} 94 \mathrm{~m}(\mathrm{~F} 46 \mathrm{~N}), 38^{\circ} 25.21^{\prime} \mathrm{S} 55^{\circ} 39.78^{\prime} \mathrm{W} 94 \mathrm{~m} \\
(\mathrm{~F} 50 \mathrm{~N}), 41^{\circ} 37.65^{\prime} \mathrm{S} 58^{\circ} 01.31^{\prime} \mathrm{W} 96 \mathrm{~m}(\mathrm{~F} 10 \mathrm{~S}), 41^{\circ} 38.58^{\prime} \\
\text { S } 58^{\circ} 02.36^{\prime} \mathrm{W} 96 \mathrm{~m}(\mathrm{~F} 17 \mathrm{~S})\end{array}$ \\
\hline Eurypon sp. & $\mathrm{x}$ & & & $38^{\circ} 25.21^{\prime} \mathrm{S} 55^{\circ} 39.76^{\prime} \mathrm{W} 94 \mathrm{~m}(\mathrm{~F} 15 \mathrm{AN})$ \\
\hline Halichondria aff. panicea & $\mathrm{x}$ & & & $39^{\circ} 09.48^{\prime} \mathrm{S} 55^{\circ} 49.78^{\prime} \mathrm{W} 106 \mathrm{~m}(\mathrm{~F} 36 \mathrm{~N})$ \\
\hline Haliclona (Haliclona) sp. 1 & $\mathrm{x}$ & & & $\begin{array}{l}39^{\circ} 09.48^{\prime} \mathrm{S} 55^{\circ} 49.78^{\prime} \mathrm{W} 106 \mathrm{~m}(\mathrm{~F} 37 \mathrm{~N}), 38^{\circ} 12.72^{\prime} \mathrm{S} 55^{\circ} \\
37.77^{\prime} \mathrm{W} 94 \mathrm{~m}(\mathrm{~F} 39 \mathrm{~N})\end{array}$ \\
\hline Haliclona (Soestella) sp. & $\mathrm{x}$ & & & $\begin{array}{l}38^{\circ} 15.07^{\prime} \mathrm{S} 55^{\circ} 25.37^{\prime} \mathrm{W} 117 \mathrm{~m}(\mathrm{~F} 42 \mathrm{~N}), 39^{\circ} 43.34^{\prime} \mathrm{S} 56^{\circ} \\
17.25^{\prime} \mathrm{W} 89 \mathrm{~m}(\mathrm{~F} 18 \mathrm{~S})\end{array}$ \\
\hline Haliclona (Reniera) topsenti & $\mathrm{x}$ & & & $38^{\circ} 37.22^{\prime} \mathrm{S} 55^{\circ} 47.53^{\prime} \mathrm{W} 89 \mathrm{~m}(\mathrm{~F} 44 \mathrm{~N})$ \\
\hline Haliclona (Gellius) sp. & $\mathrm{x}$ & & & $41^{\circ} 57.06^{\prime}$ S $58^{\circ} 15.48^{\prime} \mathrm{W} 109 \mathrm{~m}$ (F19S) \\
\hline
\end{tabular}

sponge is settled near the siphonal area of the gastropod shell and covers part of the last whorl and part of the spire (Fig. 3a). The surface is smooth when dermal membrane is present, but hispid, because of echinating spicules, when the ectosome is absent.
Skeleton. The ectosome consists of a dermal membrane of organic matrix that contains the microscleres (Fig. 3b) and it is supported by the ends of the choanosomal tracts. The choanosomal skeleton presents plumose tracts composed of and echinated 
Table 1 (continued)

\begin{tabular}{|c|c|c|c|c|}
\hline \multirow{3}{*}{$\begin{array}{l}\text { Hymedesmia (Stylopus) } \\
\text { antarctica Hentschel, } 1914\end{array}$} & & $x$ & & $41^{\circ} 22.25^{\prime} \mathrm{S} 57^{\circ} 34.47^{\prime} \mathrm{W} 111 \mathrm{~m}(\mathrm{~F} 3 \mathrm{~S})$ \\
\hline & $\mathrm{x}$ & & & 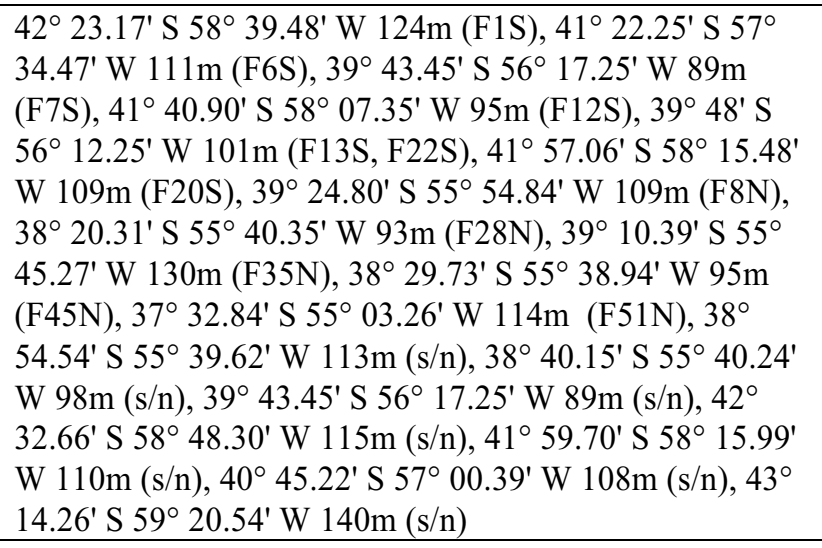 \\
\hline & & & $\mathrm{x}$ & $39^{\circ} 15.18^{\prime} \mathrm{S} 55^{\circ} 47.89^{\prime} \mathrm{W} 123 \mathrm{~m}(\mathrm{~s} / \mathrm{n})$ \\
\hline $\begin{array}{l}\text { Iophon proximum (Ridley, } \\
\text { 1881) }\end{array}$ & $\mathrm{x}$ & & & $41^{\circ} 38.58^{\prime} \mathrm{S} 58^{\circ} 02.36^{\prime} \mathrm{W} 96 \mathrm{~m}(\mathrm{~F} 5 \mathrm{~S})$ \\
\hline Iophon sp. & $\mathrm{x}$ & & & $39^{\circ} 24.53^{\prime} \mathrm{S} 55^{\circ} 56.20^{\prime} \mathrm{W} 107 \mathrm{~m}(\mathrm{~F} 31 \mathrm{BN})$ \\
\hline $\begin{array}{l}\text { Myxilla (Styloptilon) canepai } \\
\text { sp. nov. }\end{array}$ & $\mathrm{x}$ & & & $\begin{array}{l}38^{\circ} 40.17^{\prime} \mathrm{S} 55^{\circ} 50.06^{\prime} \mathrm{W} 87 \mathrm{~m}(\mathrm{~F} 26 \mathrm{~N}) \mathrm{HOLOTYPE} \\
38^{\circ} 25.21^{\prime} \mathrm{S} 55^{\circ} 39.76^{\prime} \mathrm{W} 94 \mathrm{~m}(\mathrm{~F} 15 \mathrm{BN})\end{array}$ \\
\hline $\begin{array}{l}\text { Mycale (Mycale) } \\
\text { doellojuradoi Burton, } 1940\end{array}$ & $\mathrm{x}$ & & & $43^{\circ} 18.00^{\prime} \mathrm{S} 59^{\circ} 42.52^{\prime} \mathrm{W} 101 \mathrm{~m}(\#)$ \\
\hline Phorbas sp. & $\mathrm{x}$ & & & $38^{\circ} 12.75^{\prime} \mathrm{S} 55^{\circ} 41.75^{\prime} \mathrm{W} 89 \mathrm{~m}(\mathrm{~F} 29 \mathrm{~N})$ \\
\hline $\begin{array}{l}\text { Stelodoryx argentinae } \\
\text { Bertolino, Schejter, Calcinai, } \\
\text { Cerrano \& Bremec, } 2007\end{array}$ & $\mathrm{x}$ & & & $\begin{array}{l}39^{\circ} 04.52^{\prime} \mathrm{S} 55^{\circ} 49.56^{\prime} \mathrm{W} 101 \mathrm{~m}(\mathrm{~F} 4 \mathrm{BN}), 39^{\circ} 19.84^{\prime} \mathrm{S} 55^{\circ} \\
50.33^{\prime} \mathrm{W} 121 \mathrm{~m}(\mathrm{~F} 12 \mathrm{~N}), 39^{\circ} 00.04^{\prime} \mathrm{S} 55^{\circ} 41.60^{\prime} \mathrm{W} 117 \mathrm{~m} \\
(\mathrm{~F} 14 \mathrm{~N})\end{array}$ \\
\hline $\begin{array}{l}\text { Stelodoryx cribrigera (Ridley } \\
\text { \& Dendy, 1886) }\end{array}$ & $\mathrm{x}$ & & & 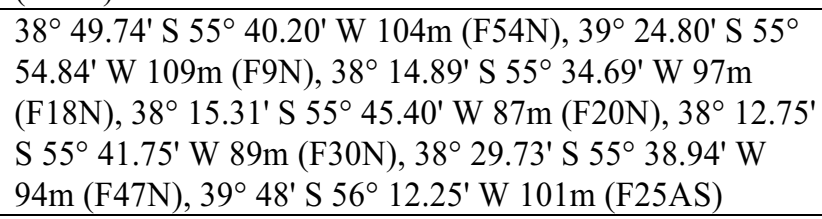 \\
\hline $\begin{array}{l}\text { Suberites cf. montiniger } \\
\text { sensu Topsent, } 1915\end{array}$ & $\mathrm{x}$ & & & $38^{\circ} 40.17^{\prime} \mathrm{S} 55^{\circ} 50.06^{\prime} \mathrm{W} 87 \mathrm{~m}(\mathrm{~F} 25 \mathrm{AN})$ \\
\hline Suberites sp. & $\mathrm{x}$ & & & $39^{\circ} 48^{\prime} \mathrm{S} 56^{\circ} 12.25^{\prime} \mathrm{W} 101 \mathrm{~m}(\mathrm{~F} 25 \mathrm{AS})$ \\
\hline \multirow[t]{2}{*}{$\begin{array}{l}\text { Tedania }(\text { Trachytedania }) \\
\text { mucosa Thiele, } 1905\end{array}$} & $\mathrm{x}$ & & & $\begin{array}{l}39^{\circ} 24.80^{\prime} \mathrm{S} 55^{\circ} 54.84^{\prime} \mathrm{W} 109 \mathrm{~m}(\mathrm{~F} 1 \mathrm{~N}), 39^{\circ} 24.66^{\prime} \mathrm{S} 55^{\circ} \\
58.28^{\prime} \mathrm{W} 103 \mathrm{~m}(\mathrm{~F} 2 \mathrm{~N}), 37^{\circ} 50.28^{\prime} \mathrm{S} 55^{\circ} 20.36^{\prime} \mathrm{W} 106 \mathrm{~m} \\
(\mathrm{~F} 16 \mathrm{~N}), 39^{\circ} 04.52^{\prime} \mathrm{S} 55^{\circ} 49.56^{\prime} \mathrm{W} 101 \mathrm{~m}(\mathrm{~F} 4 \mathrm{AN}), 38^{\circ} \\
44.74^{\prime} \mathrm{S} 55^{\circ} 39.51^{\prime} \mathrm{W} 103 \mathrm{~m}(\mathrm{~F} 33 \mathrm{~N})\end{array}$ \\
\hline & & $\mathrm{x}$ & & $41^{\circ} 54.90^{\prime} \mathrm{S} 58^{\circ} 13.17^{\prime} \mathrm{W} 107 \mathrm{~m}(\mathrm{~s} / \mathrm{n})$ \\
\hline $\begin{array}{l}\text { Tedania (Trachytedania) } \\
\text { spinata (Ridley, 1881) }\end{array}$ & $\mathrm{x}$ & & & $\begin{array}{l}38^{\circ} 15.07^{\prime} \mathrm{S} 55^{\circ} 25.37^{\prime} \mathrm{W} 117 \mathrm{~m}(\mathrm{~F} 40 \mathrm{~N}), 38^{\circ} 15.07^{\prime} \mathrm{S} 55^{\circ} \\
25.37^{\prime} \mathrm{W} 117 \mathrm{~m}(\mathrm{~F} 41 \mathrm{~N}), 39^{\circ} 48^{\prime} \mathrm{S} 56^{\circ} 12.25^{\prime} \mathrm{W} 101 \mathrm{~m} \\
(\mathrm{~F} 25 \mathrm{BS})\end{array}$ \\
\hline
\end{tabular}

exclusively by acanthostyles (Fig. 3c,d); in the terminal part of these tracts, tornotes, organized in bouquets, support the dermal membrane. Part of the dermal membrane is supported also by acanthostyles, but this could be due to a partial collapse of the skeleton structure when dried.
Spiculation. (1) Straight entirely spined acanthostyles, with conical spines, mainly concentrated at the head (Fig. 4a), 77.5-144 × 5-12.5 $\mu \mathrm{m}$. Thinner measures correspond to spicules in formation (Fig. 4a). (2) Anisodiametric, mucronate and frequently curved anisotornotes (Fig. 4b), 127.5-162.5 × 2.5-5 $\mu \mathrm{m}$. Two 


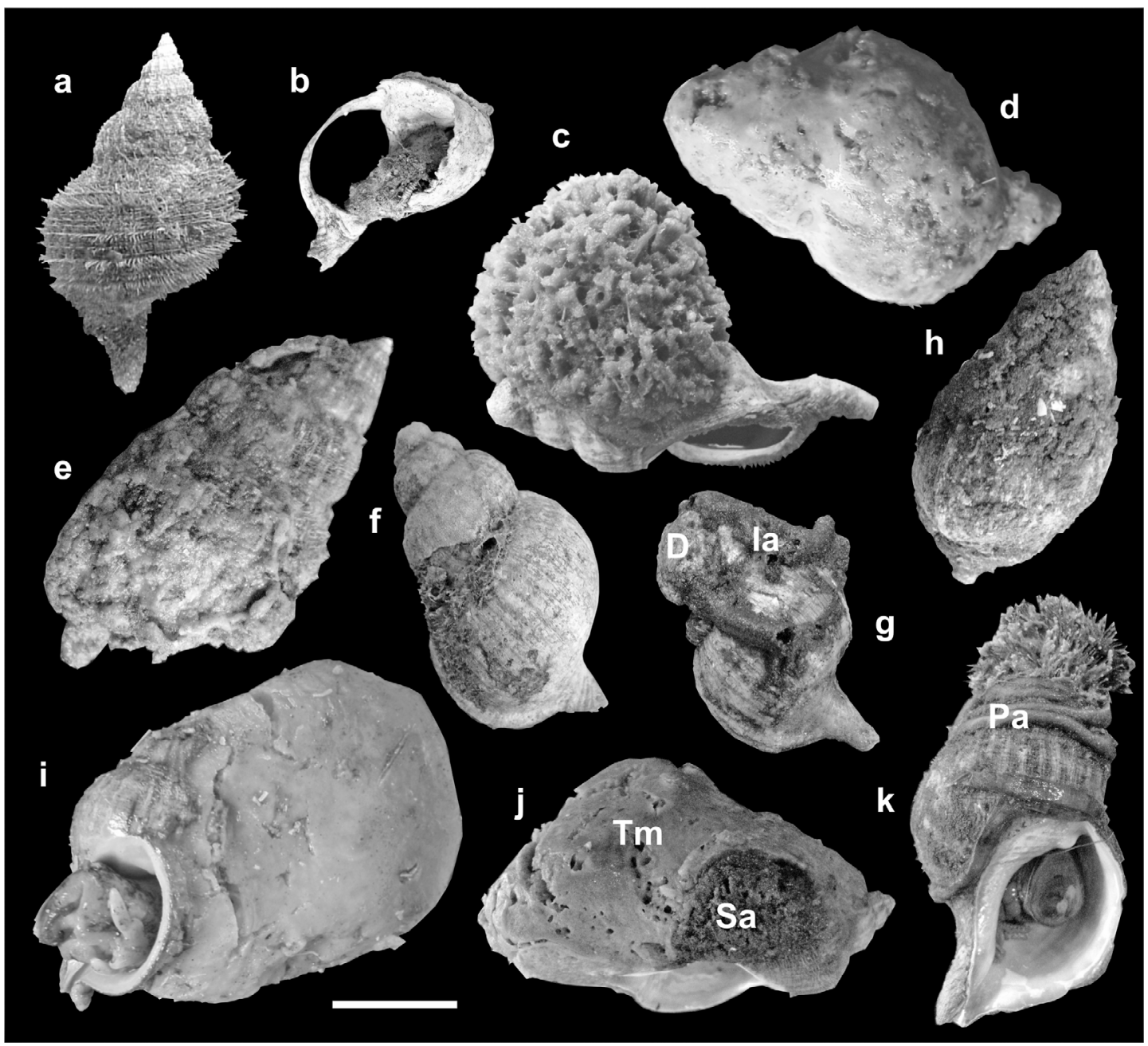

Fig. 2. Epibiotic sponges on Fusitriton magellanicus. (a) Living animal presenting a complete and hairy periostracum coating and no epibiotic species; (b) Calyx sp.; (c) Clathria (Clathria) microxa; (d) Hymedesmia (Stylopus) antarctica; (e) Suberites sp.; (f) Iophon proximum; (g) Dictyonella sp.; (h) Haliclona sp.; (i) Tedania (Trachytedania) mucosa; (j) Tedania (Trachytedania) mucosa and Stelodoryx argentinae; (k) Dictyonella hirta. Ia: Idanthyrsus armatus tubes; Pa: Potamilla antarctica tubes; Sa: Stelodoryx argentinae; Tm: Tedania mucosa. Scale bar: $35 \mathrm{~mm}$

categories of chelae: (3) the large ones are tridentate, spatuliferous isochelae, 20-37 $\mathrm{mm}$ long (Fig. 4c); (4) smaller unguiferous anchorate isochelae are 17.5-30 $\mu \mathrm{m}$ long (Fig. 4d). (5) C-shaped and contorted sigmas 27.5-40 × $2.5 \mu \mathrm{m}$ (Fig. $4 \mathrm{e}$ ).

Remarks. A second smaller specimen devoid of dermal membrane was found, attached to a Fusitriton magellanicus (F15BN, Table 1), sharing the shell substrate with a specimen of Eurypon sp.

The holotype presented the plumose skeleton described for the subgenus Styloptilon, consisting of choanosomal spicule tracts of acanthostyles, echinated by similar acanthostyles; bouquets of tornotes at the ends of the tracts supported the dermal membrane, charged with the microscleres and also tangential tornotes. According to Van Soest et al. (2011), there are presently 3 known species of Myxilla (Styloptilon): M. (Styloptilon) anchorata (Bergquist \& Fromont, 1988), M. (Styloptilon) ancorata (Cabioch, 1968) and M. (Styloptilon) acanthotornota Goodwin, Jones, Neely \& Brickle 2011. Thus, M. (Styloptilon) canepai sp. nov. is the fourth species belonging to this subgenus. In contrast to the other species of this subgenus, our species has only one type of acanthostyle in a wide range, although thinner acanthostyles in formation were also found. M. (Styloptilon) anchorata differs from our species as it is orange when fresh, has larger acanthostyles $(165-265 \times 5.5-11 \mu \mathrm{m})$ and tornotes $(140-190 \times 3.5-8 \mu \mathrm{m})$, but smaller chelae (23-28 $\mu \mathrm{m})$ and sigmas $(20-29 \mu \mathrm{m})$. Also, the shape of tornotes is different in the 2 species, as in $M$. (Styloptilon) anchorata they are isodiametric and often have 

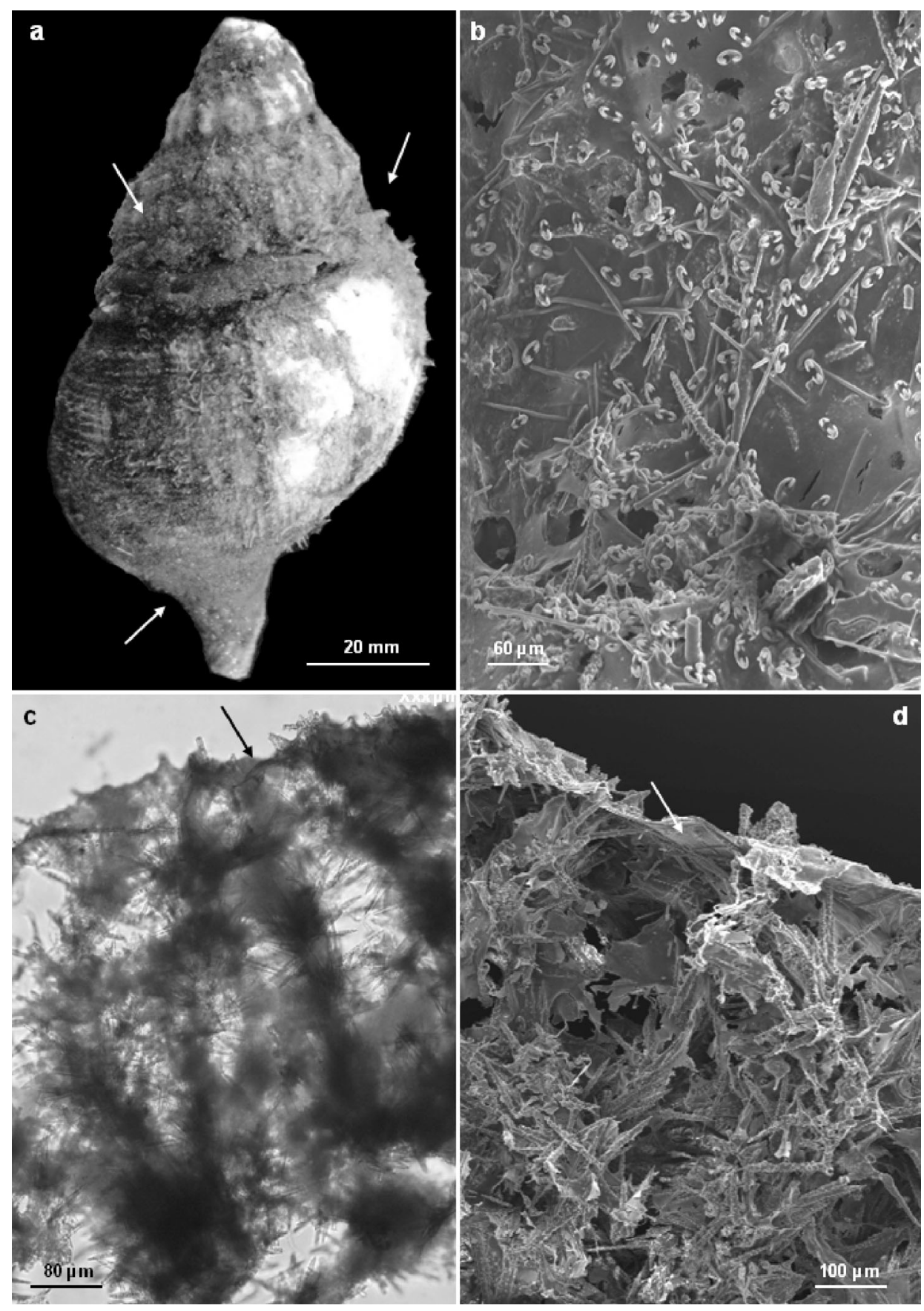

Fig. 3. (a) Fusitriton magellanicus encrusted by Myxilla (Styloptilon) canepai sp. nov. (arrows). (b) Dermal membrane with numerous scattered microscleres. (c,d) Cross-section of the plumose choanosomal skeleton; at the end of the branch, tornotes support the dermal membrane (arrows)

a slightly tylote head. Moreover, the areolate pores and the marked subdermal spaces of the ectosomal region are not present in the new species. M. (Styloptilon) canepai sp. nov. differs from M. (Styloptilon) ancorata because the latter has larger non-flexuous tornotes $(140-200 \times 2.5-5 \mu \mathrm{m})$ and larger acanthostyles (up to $280 \times 10 \mu \mathrm{m}$ ). Finally, the new species dif- fers from M. (Styloptilon) acanthotornota in having the microscleres only in the dermal membrane, a different morphology of the chelae, smaller acanthostyles and, finally, lacking the spines in the tornotes.

\section{DISCUSSION}

In the present study, we found that 26 sponge taxa 


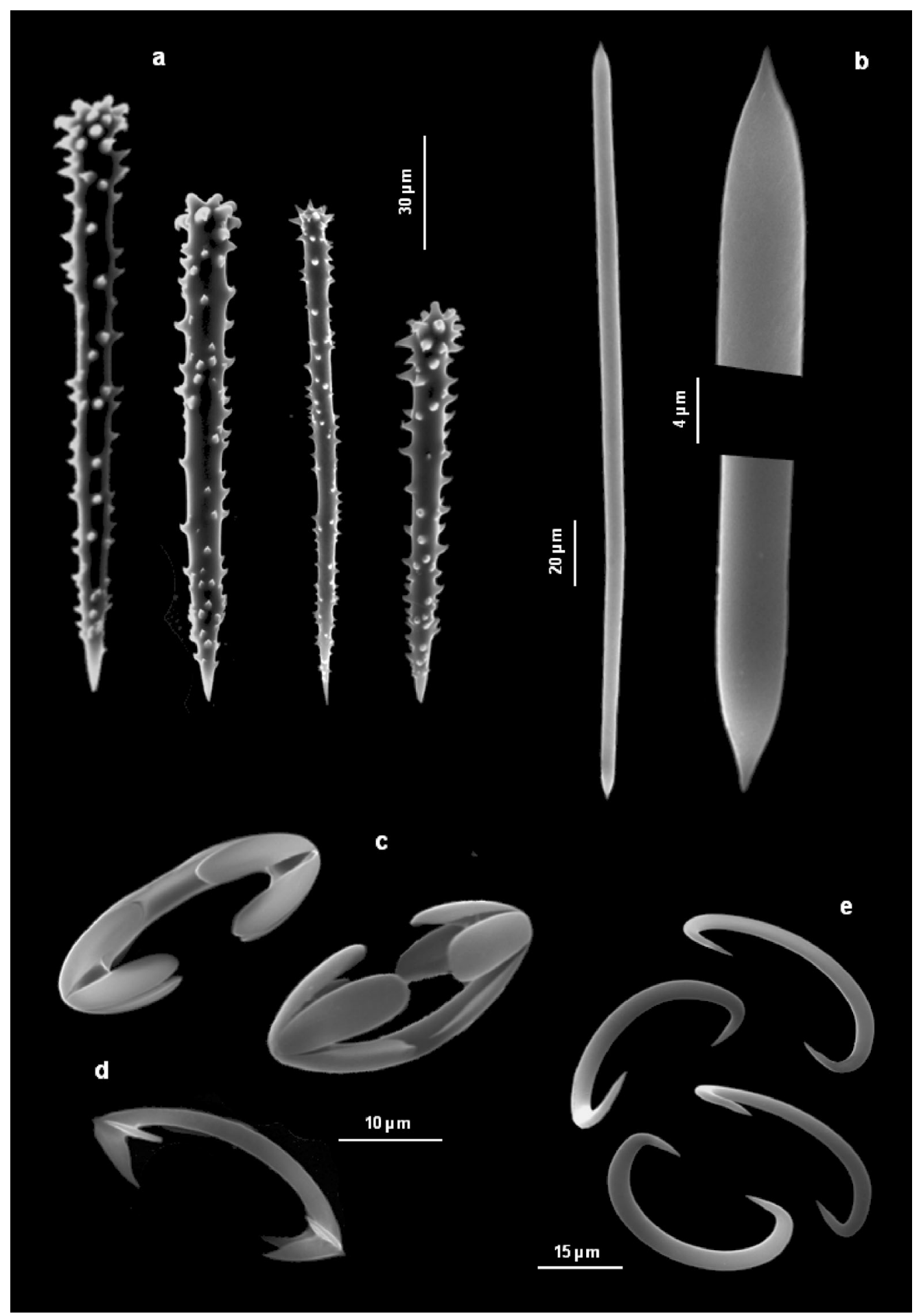

Fig. 4. SEM images of spicules. (a) Spined acanthostyles of different sizes; (b) anisotornote with magnification of the mucronate extremities; (c) spatuliferous anchorate chelae; (d) unguiferous anchorate chelae; and (e) C-shaped and contorted sigmas

encrusted approximately $21 \%$ of the specimens of Fusitriton magellanicus (living organisms and empty or pagurized shells). A few species (Hymedesmia [Stylopus] antarctica, Tedania [Trachytedania] mu- cosa and Suberites spp.) were usually found encrusting and covering more than $60 \%$ of the shell surface. Striking examples of sponge epibiosis included some T. (Trachytedania) mucosa specimens (Fig. 2i,j) that 
were found reaching 2 or 3 times the volume of the living gastropod, resembling a 'mobile sponge' (Van Soest 1993). This species has been frequently collected in the Argentine Sea (Desqueyroux-Faúndez \& Van Soest 1996, López Gappa \& Landoni 2005), and was also registered by the authors of the present study in previous surveys (Bertolino et al. 2007, Schejter et al. 2008).

Studies regarding the benefits and disadvantages of gastropod-sponge associations are rare. The most frequent ones are related to the association between siliquariids and sponges (e.g. Pansini et al. 1999) and also to the infestation of boring sponges (e.g. Stefaniak et al. 2005), which can be very disadvantageous to the gastropod. Other studies of mollusk-sponge associations involve bivalves and, except for the boring sponges, most of these relationships are advantageous for both partners (see Wulff 2006 for a revision). Additionally, some studies show a very particular relationship between hermit crabs and sponges, also referred to as 'mobile sponges', which tends to be advantageous for both partners (see Wahl 2008 for a review on epibiosis and Wulff 2006 for a review on sponge associations), increasing protection from predators for the crustacean and food availability for the sponge or also widening the dispersal opportunities for the sessile organism. Epibionts are not always helpful for the host organism, and relationships can shift from positive to negative in relation to the habitat (Wahl 2009). Epibionts can increase the visibility of prey (Threlkeld \& Willey 1993), limit the possibility of escape (Cerrano et al. 2006) or reduce recruitment (Cerrano et al. 2001). However, the association between Tedania mucosa and Fusitriton magellanicus is probably advantageous for both partners: the sponge acquires mobility and probably prevents colonization of the gastropod from boring organisms; the gastropod gains camouflage and thus may also be protected from predators. F. magellanicus is an intermediate predator in the study area, feeding mainly on scallops, but could be preyed upon by some of the starfishes in the area (mostly pterasterids) (Botto et al. 2006). Although not yet tested, given the presence of a dense mucus secretion produced by this sponge species, it is possible that some kind of chemical defense could be also acting. Other Tedania species are capable of producing allelochemical compounds that, having antibacterial and antifungal activity, may act as antipredation and antifouling substances, or have been found to produce some kind of irritation in the predator tissues (e.g. Muricy et al. 1993, Monks et al. 2002, Jimenez et al. 2004, Isbister \& Hooper 2005).
Although the gastropods hosted mainly one sponge, cases of simultaneous encrustation by 2 sponge species were found (Tedania mucosa + Stelodoryx argentinae; Suberites sp. + Tedania spinata; Suberites montiniger + Clathria sp.; Dictyonella hirta + Clathria antarctica, Eurypon sp. + Myxilla [Styloptilon] canepai sp. nov.; Chalinula sp. + Iophon sp.; Hymedesmia [Stylopus] antarctica + Clathria [Microciona] sp.). In a few other studied specimens, a very incipient coverage of a second unidentified sponge was found. According to Wulff (2006), in the majority of the cases, individuals of one sponge species growing over or adhering to another sponge species were found to be beneficial to both of them, although in some particular cases, related to very different growth rates or chemical mediation, competitive exclusion was demonstrated. Even so, sponges have been frequently found sharing the gastropod shells with other epibiotic invertebrates (see Schejter et al. 2011) and Hiatella meridionalis ( $\mathrm{d}$ 'Orbigny 1846) has frequently been found partially covered by Clathria sp., Amphilectus fucorum sensu Burton, 1932, Myxilla (Styloptilon) canepai sp. nov. and Haliclona (Haliclona) sp. As previously discussed, to detect the competition between epibiotic species hosted by F. magellanicus was not the objective of the present study. However, sponges are probably competing for free space (e.g. Fig. 2g,j,k) and are able to overgrow and cover other epibionts that could eventually die (e.g. bryozoan colonies and polychaete tubes sometimes found under the sponge cover). In this sense, it is known that Iophon proximum successfully competes against bryozoans in $Z y$ gochlamys patagonica living specimens in the same habitat (López Gappa \& Landoni 2007). In many of the sampled gastropods, dead bryozoan colonies and empty polychaete tubes were found after removing the sponge. However, it is not possible to assess whether the sponge settled after the other animals had died. Although not tested specifically for sponges, the epibiotic coverage of the shell is also related to the shell size and to the presence of the hairy periostracum (Schejter et al. 2011); the F. magellanicus specimens heavily encrusted by Tedania spp., Suberites sp. and Hymedesmia (Stylopus) anctarcticus were always larger than $75 \mathrm{~mm}$.

Out of a total of 30 sponge taxa found encrusting Fusitriton magellanicus shells (26 from the present study plus 4 previous records from selected samples collected in the same area by the authors of this paper [Schejter et al. 2006, 2008]) only 3 (Mycale doellojuradoi, Hymedesmia [Stylopus] antarctica and Dictyonella hirta sensu Burton, 1932) were previously recorded as epibiotic on this gastropod species. 
Only 7 species were previously registered for Argentinean waters (Tedania mucosa, Tedania spinata, Amphilectus fucorum sensu Burton, 1932, Callyspongia ramosa, Haliclona [Reniera] topsenti (Thiele, 1905), Iophon proximum and Halichondria aff. panicea). The species Clathria (Microciona) antarctica and Stelodoryx cribrigera extended their distribution northwards: the former (as C. toxifera) was previously recorded from Antarctica and Malvinas Islands, the latter from Chile and Malvinas. We also recorded for the second time after its description (Bertolino et al. 2007) the species Stelodoryx argentinae.

Four species (Suberites montiniger, Dictyonella hirta, Amphilectus fucorum and Halichondria aff. panicea) are of doubtful identification. In the first case, Pseudosuberites montiniger (Carter, 1880) was described for the Arctic Ocean as Suberites, whereas Topsent (1915) recorded it for Antarctica. Van Soest et al. (2011) report this species as belonging to the genus Pseudosuberites. In agreement with Campos et al. (2007), we also collected a specimen that matched the general description of the species, especially regarding the shape and size of the spicules and the sponge morphology; the main difference with the species described by Carter (1880) is that the skeletal organization in our specimen is typical of a Suberites species. However, we agree on the fact that the bipolar distribution of Pseudosuberites montiniger deserves a revision that is beyond the scope of this study, this will be investigated in depth in a further manuscript. Similarly, the species recorded as Dictyonella hirta (Topsent, 1889) sensu Burton (1932) was first described for the Campeche Bank (Gulf of Mexico) and later identified by Burton (1932, 1940) for Argentinean waters. Our specimen matched the description of the species, and, in agreement with Burton (1940), was also recorded attached to Fusitriton magellanicus. It is unlikely that this species may have such an extensive distribution and our further studies should clarify this point. Equally, van Soest et al. (2011) stated that the Argentine Sea was not a valid distribution of Amphilectus fucorum, another species also described for the Northern Hemisphere. This fact denotes a doubtful identification of the material examined by Burton (1932) and the previous finding of this species by the present authors in Bertolino et al. (2007). This species should be revised in order to establish whether it could represent a new species, as found in other cases (Uriz et al. 2011). These questions will be clarified in a future study. In addition, further study is necessary of the specimens identified here attributed to Halichondria aff. panicea; although $H$. panicea was mentioned sev- eral times for Argentinean waters (see López Gappa \& Landoni 2005 and references therein), it is unlikely that this Atlanto-Mediterranean species has a cosmopolitan distribution - its records from the Southern Ocean are considered doubtful (Erpenbeck \& Van Soest 2002).

In the present study, we describe one species new to science: Myxilla (Styloptilon) canepai. Several other specimens did not match any of the known species in the area and were tentatively identified as Phorbas sp., Dictyonella sp., Clathria (Microciona) sp.

Considering that the study area is a soft bottom and the only substrates available for settlement of sessile species are hard parts of other living organisms, empty shells or carapaces, our results confirm that the shells of the gastropod Fusitriton magellanicus play a very important role for settlement of sessile species, especially sponges, and at present they represent the substrate hosting the highest species richness of sponges in the area $(\mathrm{N}=30)$, and host a total of (at least) 56 epibiotic taxa considering other invertebrate taxa mentioned by Schejter et al. (2011). The other mollusk that plays an important role in providing substrate for sponges is the Patagonian scallop Zygochlamys patagonica, hosting at least 15 sponge species (Schejter et al. 2008, 2010), most of them shared with F. magellanicus. Other available substrates for sponges in the study area were crustacean carapaces, polychaete tubes, dead corals and Rajoidea egg capsules (Schejter et al. 2010). It is probable that only living $F$. magellanicus (not the empty or pagurized shells) are important as settlement substrate for sponges in the study area, as the few species found in empty shells could be considered as rare occurrences.

Acknowledgements. The authors thank technicians and colleagues at INIDEP (M. Escolar, V. Souto, M. Di pace, Á. Marecos, M. Schwartz and R. Díaz) who assisted during general sampling procedures. We would also like to thank J. Cristobo and M. Pansini for their valuable comments at previous stages of this manuscript, and three anonymous reviewers for their useful suggestions. This study was partially supported by INIDEP, CONICET, PICT 20072200 and PICT 2008 1119, Lerner Gray Grant for Marine Research to L.S. This is INIDEP Contribution 1671.

\section{LITERATURE CITED}

Acha EM, Mianzan H, Guerrero R, Favero M, Bava J (2004) Marine fronts at the continental shelves of austral South America: physical and ecological processes. J Mar Syst 44:83-105

Bertolino M, Schejter L, Calcinai B, Cerrano C, Bremec C (2007) Sponges from a submarine canyon of the Argentine Sea. In: Custódio MR, Hajdu E, Lôbo-Hajdu G, 
Muricy G (eds) Porifera research: biodiversity, innovation, sustainability. Museu Nacional, Rio de Janeiro, p 189-201

Bogazzi E, Baldoni A, Rivas A, Martos P and others (2005) Spatial correspondence between areas of concentration of Patagonian scallop (Zygochlamys patagonica) and frontal systems in the southwestern Atlantic. Fish Oceanogr 14:359-376

Botto F, Bremec C, Marecos A, Schejter L, Lasta M, Iribarne O (2006) Identifying predators of the SW Atlantic Patagonian scallop Zygochlamys patagonica using stable isotopes. Fish Res 81:45-50

Bremec CS, Lasta ML (2002) Epibenthic assemblage associated with scallop (Zygochlamys patagonica) beds in the Argentine shelf. Bull Mar Sci 70:89-105

Bremec C, Marecos A, Schejter L, Lasta M (2003) Guía técnica para la identificación de invertebrados epibentónicos asociados a bancos de vieira patagónica (Zygochlamys patagonica) en el Mar Argentino. Publicación Especial INIDEP, Mar del Plata

> Bremec C, Escolar M, Schejter L, Genzano G (2008) Primary settlement substrate of scallop Zygochlamys patagonica (King \& Broderip, 1832) (Mollusca: Pectinidae) in fishing grounds in the Argentine Sea. J Shellfish Res 27:273-280

Burton M (1932) Sponges. Discov Rep 6:237-392

Burton M (1940) Las esponjas marinas del Museo Argentino de Ciencias Naturales (Parte 1). An Mus Argent Cienc Nat Bernardino Rivadavia 40:95-121

> Campos M, Mothes B, Veitenheimer Mendes IL (2007) Antarctic sponges (Porifera, Demospongiae) of the South Shetland Islands and vicinity. Part I. Spirophorida, Hadromerida, Halichondrida and Haplosclerida. Rev Bras Zool 24:687-708

- Carreto JI, Benavides HR, Negri RM, Glorioso PD (1986) Toxic red-tide in the Argentine Sea. Phytoplankton distribution and survival of the toxic dinoflagellate Gonyaulax excavata in a frontal area. J Plankton Res 8:15-28

Carter HJ (1880) Description of two new sponges. In: d'Urban WSM (ed) The zoology of Barents Sea. Ann Mag Nat Hist (5) 6(34):253-277

> Cerrano C, Puce S, Chiantore M, Bavestrello G, CattaneoVietti R (2001) The influence of the epizoic hydroid Hydractinia angusta on the recruitment of the Antarctic scallop Adamussium colbecki. Polar Biol 24:577-581

Cerrano C, Calcinai B, Bertolino M, Valisano L, Bavestrello G (2006) Epibionts of the scallop Adamussium colbecki in the Ross Sea, Antarctica. Chem Ecol 22 (Suppl 1): S235-S244

Desqueyroux-Faúndez R, Van Soest RWM (1996) A review of Iophonidae, Myxillidae and Tedaniidae occurring in the South East Pacific (Porifera: Poecilosclerida). Rev Suisse Zool 103:3-79

Erpenbeck D, Van Soest RWM (2002) Family Halichondriidae Gray, 1867. In: Hooper JNA, Van Soest RWM (eds) Systema Porifera. A guide to the classification of sponges. Kluwer Academic/Plenum Publishers, New York, Boston, Dordrecht, London, Moscow, p 787-816

Escolar M, Schejter L, Excoffon A, Bremec C (2008) Caracoles volútidos + anémonas: asociaciones en bancos de vieira patagónica del Mar Argentino. VII CLAMA, 3-7 November 2008, Valdivia, Chile, p 149 (Abstract)

Isbister GK, Hooper JNA (2005) Clinical effects of stings by sponges of the genus Tedania and a review of sponge stings worldwide. Toxicon 46:782-785

Jimenez PC, Teixeira GLS, Wilke DV, Nogueira NAP, Hajdu E, Pessoa C, Moraes M, Costa-Lotufo LV (2004) Cytotoxic and antimicrobial activities hydro-methanolic extracts of sponges (Porifera) from Ceara State Brazil. Arq Cienc Mar 37:85-92

> Kimura M, Weiss GW (1964) The stepping stone model of population structure and the decrease of genetic correlation with distance. Genetics 49:561-576

Largier JL (1993) Estuarine fronts: How important are they? Ecology 16:1-11

Lasta ML, Bremec CS (1998) Zygochlamys patagonica in the Argentine sea: a new scallop fishery. J Shellfish Res 17: 103-111

López Gappa J, Landoni NA (2005) Biodiversity of Porifera in the Southwest Atlantic between $35 \mathrm{~S}$ and $56 \mathrm{~S}$. Rev Mus Argent Cienc Nat 7:191-219

> López Gappa J, Landoni NA (2007) Smaller host size and monopolization of space in Patagonian scallops, Psychrochlamys patagonica, covered by the sponge Iophon proximum. J Mar Biol Assoc UK 87:927-931

> López Gappa J, Landoni NA (2009) Space utilisation patterns of bryozoans on the Patagonian scallop Psychrochlamys patagonica. Sci Mar 73:161-171

Mann KH, Lazier JRN (1996) Dynamics of marine ecosystems: biological-physical interactions in the oceans. Blackwell Science, Boston, MA

> Monks NR, Lerner C, Henriques AT, Farias FM and others (2002) Anticancer, antichemotactic and antimicrobial activities of marine sponges collected off the coast of Santa Catarina, southern Brazil. J Exp Mar Biol Ecol 281: $1-12$

Muricy G, Hajdu E, Araujo FV, Hagler AN (1993) Antimicrobial activity of Southwestern Atlantic shallow-water marine sponges (Porifera). Sci Mar 57:427-432

Pansini M, Cattaneo-Vietti R, Shiaporelli S (1999) Relationship between sponges and a taxon of obligatory inqilines: the siliquarid mollusks. Mem Queensl Mus 44: 427-437

Parker G, Paterlini CM, Violante RA (1997) El fondo marino. In: Boschi EE (ed) El Mar Argentino y sus recursos pesqueros. INIDEP, Mar del Plata, p 65-87

Rivas AL (2006) Quantitative estimation of the influence of surface thermal fronts over chlorophyll concentration at the Patagonian shelf. J Mar Syst 63:183-190

Romero SI, Piola AR, Charo M, Eiras Garcia CA (2006) Chlorophyll a variability off Patagonia based on SeaWiFS data. J Geophys Res 111:C05021, doi:10.1029/2005JC 003244

Rützler K (1978) Sponges in coral reefs. In: Stoddard DR, Johannes RE (eds) Coral reefs: research methods. Monographs of Oceanographic Methodology 5. UNESCO, Paris, p 299-313

> Schejter L, Bremec C (2007) Benthic richness in the Argentine continental shelf: the role of Zygochlamys patagonica (Mollusca: Bivalvia: Pectinidae) as settlement substrate. J Mar Biol Assoc UK 87:917-925

Schejter L, Bremec C (2008) En cuánto contribuyen los epibiontes de moluscos a la riqueza específica bentónica asociada al frente de talud del Mar Argentino? VII CLAMA, 3-7 November 2008, Valdivia, Chile, p 149-150 (Abstract)

Schejter L, Bremec C (2009) Epibiosis contest at Zygochlamys patagonica fishing grounds: Which is the winner? 17th International Pectinid Workshop, 22-28 April 2009, Santiago de Compostela, Spain, p 143-144 (Abstract)

Schejter L, Spivak E (2005) Morphometry, sexual maturity, fecundity and epibiosis of the South American spider 
crab Libidoclaea granaria (Brachyura: Majoidea). J Mar Biol Assoc UK 85:857-863

Schejter L, Calcinai B, Cerrano C, Bertolino M, Pansini M, Giberto D, Bremec C (2006) Porifera from the Argentine Sea: diversity in Patagonian scallop beds. Ital J Zool 73: 373-385

Schejter L, Bertolino M, Calcinai B, Cerrano C, Bremec C (2008) Los moluscos como sustrato de asentamiento de esponjas en áreas del frente de talud del Mar Argentino. VII CLAMA, 3-7 November 2008, Valdivia, Chile, p 150 (Abstract)

Schejter L, Bertolino M, Calcinai B, Cerrano C, Bremec C (2010) Choosing settlement substrate: sponges in softbottom assemblages at the shelf-break frontal area, Argentine Sea. VIII World Sponge Conference, 18-22 September 2010, Girona, Spain, p 326 (Abstract)

Schejter L, Escolar M, Bremec C (2011) Variability in epibiont colonization of shells of Fusitriton magellanicus (Gastropoda) on the Argentinean shelf. J Mar Biol Assoc UK 91:897-906

Stefaniak LM, McAtee J, Shulman MJ (2005) The costs of being bored: effects of a clionid sponge on the gastropod Littorina littorea (L). J Exp Mar Biol Ecol 327:103-114

Threlkeld ST, Willey RL (1993) Colonization, interaction, and organization of Cladoceran epibiont communities. Limnol Oceanogr 38:584-591

Editorial responsibility: Riccardo Cattaneo-Vietti, Genova, Italy
Topsent E (1915) Spongiaires recueillis par la 'Scotia' dans l'Antarctique (1903-1904). Trans R Soc Edin 51:35-43

Uriz MJ, Gili JM, Orejas C (2011) Do bipolar distributions exist in marine sponges? Stylocordyla chupachups sp. nov. (Porifera: Hadromerida) from the Weddell Sea (Antarctic), previously reported as $S$. borealis (Lovén, 1868). Polar Biol 34:243-255

Van Soest RWM (1993) Distribution of sponges on the Mauritanian continental shelf. In: Wolff WJ, van der Land J, Nienhuis PH, de Wilde PAWJ (eds) Ecological studies in the coastal waters of Mauritania. Hydrobiologia 258: 95-106

Van Soest RWM, Boury-Esnault N, Hooper JNA, Rützler K and others (2011) World Porifera database. Available at www.marinespecies.org/porifera

Wahl M (1989) Marine epibiosis. I. Fouling and antifouling: some basic aspects. Mar Ecol Prog Ser 58:175-189

Wahl M (2008) Ecological lever and interface ecology: epibiosis modulates the interactions between host and environment. Biofouling 24:427-438

Wahl M (2009) Epibiosis: ecology, effects and defences. In: Wahl M (ed) Marine hard bottom communities. Ecological Studies 206. Springer-Verlag, Berlin, Heidelberg, p 61-72

> Wulff JL (2006) Ecological interactions of marine sponges. Can J Zool 84:146-166

Submitted: June 29, 2011; Accepted: August 19, 2011

Proofs received from author(s): October 26, 2011 